\title{
Opioid analgesic administration in patients with suspected drug use
}

\author{
Administração de analgésicos opioides em pacientes com suspeita de uso de drogas \\ Administración de analgésicos opioides en pacientes con sospecha de uso de drogas
}

\section{Maria Clara Giorio Dutra Kreling', Cibele Andrucioli de Mattos-Pimenta'}

' Universidade de São Paulo, School of Nursing, Postgraduate Program in Nursing in Adult Health. São Paulo, Brazil.

\section{How to cite this article:}

Kreling MCGD, Mattos-Pimenta CA. Opioid analgesic administration in patients with suspected drug use. Rev Bras Enferm [Internet]. 2017;70(3):626-32. DOI: http://dx.doi.org/10.1590/0034-7167-2016-0501

\section{Submission:10-13-2016 Approval: 01-18-2017}

\section{ABSTRACT}

Objective: To identify the prevalence of patients suspected of drug use according to the nursing professionals' judgement, and compare the behavior of these professionals in opioid administration when there is or there is no suspicion that patient is a drug user. Method: A cross-sectional study with 507 patients and 199 nursing professionals responsible for administering drugs to these patients. The Chi-Square test, Fisher's Exact and a significance level of $5 \%$ were used for the analyzes. Results: The prevalence of suspected patients was $6.7 \%$. The prevalence ratio of administration of opioid analgesics 'if necessary' is twice higher among patients suspected of drug use compared to patients not suspected of drug use $(p=0.037)$. Conclusion: The prevalence of patients suspected of drug use was similar to that of studies performed in emergency departments. Patients suspected of drug use receive more opioids than patients not suspected of drug use.

Descriptors: Opioid Analgesics; Drug Abuse; Nursing; Pain; Patients.

\section{RESUMO}

Objetivo: Identificar a prevalência de pacientes com suspeita de uso de drogas conforme opinião de profissionais de enfermagem e comparar a conduta desses profissionais na administração de opioides quando há ou não suspeita de que o paciente seja usuário de drogas. Método: Estudo transversal com 507 pacientes e 199 profissionais de enfermagem responsáveis pela administração de medicamentos a esses pacientes. Para as análises foram utilizados os testes de Qui-Quadrado, Exato de Fisher e um nível de significância de 5\%. Resultados: A prevalência de pacientes suspeitos foi 6,7\%. A razão de prevalência de administração de analgésicos opioides "se necessário" é duas vezes maior entre os pacientes suspeitos em relação aos não suspeitos $(p=0,037)$. Conclusão: A prevalência de suspeitos foi semelhante à de estudos realizados em departamentos de emergência. Os suspeitos de serem usuários de drogas recebem mais opioides do que os não suspeitos.

Descritores: Analgésico Opióide; Abuso de Drogas; Enfermagem; Dor; Pacientes.

\section{RESUMEN}

Objetivo: Identificar la prevalencia de pacientes con sospecha de uso de drogas de acuerdo con la opinión de los profesionales de enfermería y comparar el comportamiento de estos profesionales en la administración de opioides cuando hay o no hay sospecha de que el paciente sea un consumidor de drogas. Método: Estudio transversal con 507 pacientes y 199 enfermeras responsables de la administración de medicamentos a estos pacientes. Para el análisis se utilizó la prueba de Chi-cuadrado, la prueba exacta de Fisher y un nivel de significación del 5\%. Resultados: La prevalencia de pacientes con sospecha de uso de drogas fue del 6,7\%. La razón de prevalencia de la administración de analgésicos opioides 'si es necesario' es dos veces mayor entre los pacientes con sospecha de uso de drogas en comparación a las personas sin sospecha de uso de drogas $(p=0,037)$. Conclusión: La prevalencia de los sospechosos fue similar a los estudios llevados a cabo en los servicios de urgencias. Los pacientes sospechosos de uso de drogas reciben más opioides que los no sospechosos.

Descriptores: Analgésico Opioide; Abuso de Drogas; Enfermería; Dolor; Pacientes. 


\section{INTRODUCTION}

Caring for patients in pain is the role of nursing professionals, but many obstacles can affect this care, especially when there is coexisting drug use in the patient.

Chemical dependency has become an important public health problem and has challenged health professionals to seek to understand the profile of psychoactive substances users and reflect on the best way to deal with problems arising from this use $\mathrm{e}^{(1)}$. The subjectivity and multidetermination of the painful phenomenon make the adequate management of pain difficult, especially in situations of patients with acute pain and suspected of drug use. This reality is becoming more pronounced in hospitals, given the increased prevalence of drug use in the general population and these patients' involvement in situations of trauma and violence.

At the concomitance of pain and any drug use situation, there may be a risk of patients requesting the opioid to achieve the well-being effect and not necessarily for analgesia.

This is a complicating factor for proper care of patients in pain. The association between drug use and accidents resulting from external causes is known ${ }^{(2)}$. Because of pain resulting from injuries and traumas, these patients will receive analgesics, often opioids, and the nursing team has great responsibility in the identification of pain and in administration of analgesics (opioids or not) at fixed times and in a 'if necessary' regime.

The fears and preconceptions of health and nursing teams regarding opioids administration are known ${ }^{(3)}$. There is fear whether effects of sleepiness and respiratory depression can be life threatening. There are also preconceptions that opioids should not be given to patients with history of previous drug use, since this would accentuate dependency ${ }^{(4)}$.

Besides this situation, there is no objective method of evaluating pain. Although self-report is the best way to know the other person's pain, sometimes it can be hard to distinguish those in pain from those exaggerating to obtain opioids for psychological benefits ${ }^{(5)}$. Therefore, given the need for administration of opioid analgesics, when suspecting that the patient is a drug user, there is greater uncertainty about what to do. The combination of pain, opioid analgesia, and suspected drug use may compromise the nursing staff ability to safely judge pain intensity and the need for analgesic, increasing the likelihood of inadequate analgesia ${ }^{(6)}$.

\section{OBJECTIVES}

- To identify the prevalence of patients suspected of drug use according to nursing professionals' judgement.

- To compare these professionals' behavior in the administration of opioid analgesics when there is suspicion or there is no suspicion that the patient is a drug user.

\section{METHOD}

\section{Ethical aspects}

This research was approved by the Research Ethics Committee of the School of Nursing, University of São Paulo.

\section{Study design, location and period}

This is a cross-sectional study. Data collection was performed in four hospitals in the city of Londrina (state of Paraná), Brazil, during the first semester of 2012. For each selected patient, were interviewed three nursing professionals responsible for medication administration, one of each shift (morning, afternoon and night) to check if professionals had any suspicion that the patient was a drug user. When at least one of the professionals indicated suspicion, the patient was considered suspect.

\section{Population; inclusion and exclusion criteria}

The study was conducted with a population of 507 hospitalized patients, minimum age of 18 years, diagnosis of fractures or orthopedic surgeries, medical prescription of opioid analgesics, and nursing professionals $(N=199)$ responsible for administering drugs to these patients.

\section{Study protocol}

For the collection of patients' data, every three days, the interviewers identified on the inpatient list those who met the inclusion criteria. All patients with two days of hospitalization and who met the other inclusion criteria had the following information transcribed for the data collection instrument: socio-demographic data, diagnosis, cause of trauma and medical prescription of the previous day.

For each selected patient, were interviewed three nursing professionals responsible for medication administration; one of each shift (morning, afternoon and night) to verify if professionals suspected the patient was a drug user. If so, which characteristics and/or behaviors of these patients made them suspect of abusive use. They also identified their own conduct in face of the pain complaint and opioid analgesic request. The patient was considered suspected when at least one of the professionals indicated suspicion.

Data were collected by previously trained and paid interviewers with funds from the National Council for Scientific and Technological Development.

\section{Analysis of results and statistics}

To check if the conduct in opioid analgesic administration was different for patients suspected of drug use and patients not suspected, was used the administration outcome in the last 24 hours of opioid and non-opioid analgesics prescribed in 'if necessary' and 'fixed times' regimes. It was observed if medication was administered or not and the percentage of doses received.

Data were entered in database and analyzed with the R.2.14.1 program. To evaluate associations between categorical variables, was used the Chi-Square test; to compare the scales of two independent populations, was used the nonparametric Mann-Whitney test; and to estimate the prevalence ratio of administration of opioid and non-opioid analgesics among patients suspected and patients not suspected of drug use, was applied the Fisher's exact test, and the significance level was set at $5 \%$. 


\section{RESULTS}

Among patients $(\mathrm{N}=507)$, the female gender predominated $(71 \%), 51.6 \%$ had no partner and the majority was white (59.2\%). Regarding age groups, $34.55 \%$ were aged between 18 and 30 years and the others (30 to 70 years) were evenly distributed. Most professionals ( $N=199)$ were female $(81 \%)$, had companions $(52 \%)$, were white $(73.4 \%)$, and in the age group of 30 to 50 years $(58.8 \%)$.

The prevalence of patients suspected of drug use, according to nursing professionals' judgement, was $6.7 \%$. The frequency of suspicion was higher among males $(p<0.036)$ and in the age range of 25 to 30 years ( $p<0.001$ ). In relation to the other characteristics, race, educational level and presence of companion, there was no difference in frequency of occurrence between patients suspected of drug use and patients not suspected.

Tables 1, 2, 3 and 4 and figure 1 show the distribution of patients suspected of drug use and patients not suspected of drug use in relation to the analgesic conduct of nursing professionals.

Data in table 1 express the prevalence ratio of administration of opioid analgesics 'if necessary' is twice as high among patients suspected of drug use compared to patients not suspected of drug use ( $p=0.037$ ).

Figure 1 shows that nursing professionals administered up to $30 \%$ of the maximum possible dose of opioid 'if necessary' for patients suspected of drug use, and up to $20 \%$ for patients not suspected of drug use.

Table 2 shows that administration of non-opioid analgesics in the 'if necessary' regime did not differ between patients suspected of drug use and patients not suspected of drug use.

\section{Proportion of opioids administered if necessary}

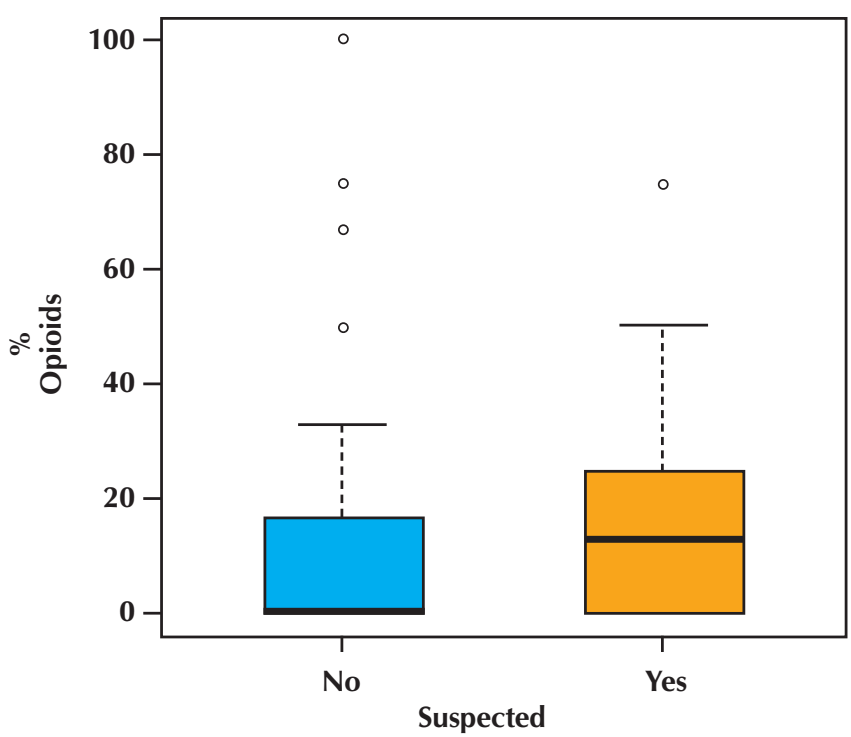

Figure 1 - Percentage distribution of opioids administered in the 'if necessary' regime in relation to the maximum possible dosage, between patients suspected of drug use and patients not suspected of drug use, Londrina, Paraná, Brazil, 2012
Table 1 - Distribution of patients suspected of drug use and patients not suspected of drug use according to opioid analgesic administration in the 'if necessary' regime, Londrina, Paraná, Brazil, 2012

\begin{tabular}{lccccccc}
\hline & \multicolumn{4}{c}{ Suspected according to at least one professional } \\
Opioid IN* & \multicolumn{2}{c}{ No } & \multicolumn{2}{c}{ Yes } & \multicolumn{2}{c}{ Total } \\
& n & $\%$ & n & $\%$ & n & $\%$ \\
\hline Not administered & 160 & 73.4 & 7 & 46.7 & 167 & 71.7 \\
Administered & 58 & 26.6 & 8 & 53.3 & 66 & 28.3 \\
Total & 218 & 100 & 15 & 100 & 233 & 100 \\
\hline
\end{tabular}

Note: ${ }^{*}$ If necessary; Fisher's $p$ value $=0,037$.

Table 2 - Distribution of patients suspected of drug use and patients not suspected of drug use according to administration of non-opioid analgesics in the 'if necessary' regime, Londrina, Paraná, Brazil, 2012

\begin{tabular}{|c|c|c|c|c|c|c|}
\hline \multirow{3}{*}{ Non-opioid IN* } & \multicolumn{6}{|c|}{ Suspected according to at least one professional } \\
\hline & \multicolumn{2}{|c|}{ No } & \multicolumn{2}{|c|}{ Yes } & \multicolumn{2}{|c|}{ Total } \\
\hline & $\mathbf{n}$ & $\%$ & $\mathbf{n}$ & $\%$ & $\mathbf{n}$ & $\%$ \\
\hline Not administered & 63 & 64.3 & 6 & 66.7 & 69 & 64.5 \\
\hline Administered & 35 & 35.7 & 3 & 33.3 & 38 & 35.5 \\
\hline Total & 98 & 100 & 9 & 100 & 107 & 100 \\
\hline
\end{tabular}

Note: ${ }^{*}$ If necessary; Fisher's $p$ value $=1$

Data in table 3 show no difference in the administration of opioids at 'fixed times' between patients suspected of drug use and those not suspected of drug use. However, for both groups, $10 \%$ of opioids prescribed at 'fixed times' was not administered.

Table 4 shows similarity in the administration of non-opioid analgesics prescribed at 'fixed times' between patients suspected of drug use and patients not suspected of drug use (around $92 \%$ ). For both groups, about $8 \%$ of non-opioid analgesics prescribed without 'fixed times' were not administered.

Table 3 - Distribution of patients suspected of drug use and patients not suspected of drug use according to administration of opioid analgesics prescribed in the 'fixed times' regime, Londrina, Paraná, Brazil, 2012

\begin{tabular}{|c|c|c|c|c|c|c|}
\hline \multirow{3}{*}{ Opioid HF* } & \multicolumn{6}{|c|}{ Suspected according to at least one professional } \\
\hline & \multicolumn{2}{|c|}{ No } & \multicolumn{2}{|c|}{ Yes } & \multicolumn{2}{|c|}{ Total } \\
\hline & $\mathbf{n}$ & $\%$ & $\mathbf{n}$ & $\%$ & $\mathbf{n}$ & $\%$ \\
\hline Not administered & 28 & 10.2 & 2 & 9.1 & 30 & 10.1 \\
\hline Administered & 247 & 89.8 & 20 & 90.9 & 267 & 89.9 \\
\hline Total & 275 & 100 & 22 & 100 & 297 & 100 \\
\hline
\end{tabular}

Note: $*$ Fixed times; Fisher's $p$ value $=1$ 
Table 4 - Distribution of patients suspected of drug use and patients not suspected of drug use according to administration of non-opioid analgesics prescribed in the 'fixed times' regime, Londrina, Paraná, Brazil, 2012

\begin{tabular}{lccccccc}
\hline & \multicolumn{4}{c}{ Suspected according to at least one professional } \\
Non-opioid FT* & \multicolumn{2}{c}{ No } & \multicolumn{2}{c}{ Yes } & \multicolumn{2}{c}{ Total } \\
& n & $\%$ & n & $\%$ & n & $\%$ \\
\hline Not administered & 25 & 7.4 & 2 & 8.7 & 27 & 7.5 \\
Administered & 311 & 92.6 & 21 & 91.3 & 332 & 92.5 \\
Total & 336 & 100 & 23 & 100 & 359 & 100 \\
\hline
\end{tabular}

Note: ${ }^{*}$ Fixed times; Fisher's $p$ value $=0.6876$

\section{DISCUSSION}

The concern with hospitalized patients who are drug users is increasing. In particular, abusive use of opioid analgesics has increased in the last decade to levels that some authors describe as 'epidemic ${ }^{\prime(7)}$, especially in the United States, Canada, Australia and New Zealand ${ }^{(8-10)}$.

In the present study, according to the judgement of nursing assistants and technicians, the prevalence of hospitalized patients suspected of drug use (licit or illicit drugs) was $6.7 \%$.

Several conditions limit the comparison of prevalence results described in other studies with results found in the present research, among which the location and types of studied population and the form of identification of users. In this study, inclusion criteria comprised patients hospitalized for at least 48 hours, who suffered trauma or had undergone orthopedic surgery, and had opioids prescribed in their medical prescriptions. Patients suspected of drug use were identified by the evaluation of nursing assistants and technicians.

However, it seems that nursing assistants and technicians were judicious in the indication of patients suspected of drug use $(6.7 \%)$ by taking into consideration the findings of a Brazilian study performed in emergency service in which the average prevalence for use of marijuana, cocaine and benzodiazepines was $7 \%{ }^{(11)}$. There was also similarity with results of the study performed in Spain, where the prevalence of cocaine user patients who sought emergency services in 30 days was $6.7 \%{ }^{(12)}$.

The frequency of suspicion was higher among males ( $p$ $<0.036$ ) in the age range of 25 to 30 years ( $p<0.001$ ). This probability is confirmed in studies describing the profile of illicit drug users linked to a health service specialized in care of drug users ${ }^{(13-15)}$, and in study with the general population ${ }^{(16)}$.

The prevalence found in the present study brings a valuable contribution, as it draws attention to the fact that only nursing professionals take daily care of potential drug users, but also the health staff in general, and they need to be prepared to provide assistance to these patients, aiming at adequate care.
Providing adequate patient care includes pain relief, regardless if the patient is a drug user. The main objective of this study was to verify if the suspicion of drug use influenced the analgesia decisions of nursing professionals, and we now analyze its results.

The suspect of the patient being a drug user may make it difficult to decide whether to administer opioid analgesics or not, for fear of contributing to the maintenance or exacerbation of addiction. The fact of drug user patients or suspected of use receiving fewer analgesics is common sense and has been cited by several authors ${ }^{(17-19)}$. However, in the present study, this fact proved to be unfounded.

The results shown in table 1 demonstrate that nursing assistants and technicians administered more opioid analgesics 'if necessary' to patients suspected of drug use than to patients not suspected of drug use $(p=0.037)$. No study reporting greater use of opioid analgesics in drug user patients or suspected of drug use was found, and this finding is the original contribution of the present study.

The characteristic behavior of drug user patients, with repetitive and insistent requests and manifestations of anxiety and irritability may also influence the decision to give or not the analgesic 'if necessary'(5,18,20), since such behavior is difficult to manage.

It is worth mentioning that professionals of the study were questioned about the characteristics and behaviors observed in patients they considered as suspected of drug use, and the most frequent responses were agitation, restlessness, aggression, anxiety, distrust, violence and constant requests of opioid analgesics. Therefore, it seems practitioners administer more opioids 'if necessary' among patients suspected of drug use in an attempt to avoid potential conflicts. Studies comparing the request for opioids 'if necessary' between drug users and non-users of drugs found that drug users asked for medication more often than non-users ${ }^{(21-22)}$.

The nursing team's understanding that pain is subjective, and there is no way to prove or deny its existence fully, and when in doubt, the best option is analgesia, may also have influenced the greater administration of opioid analgesics to patients suspected of drug use.

Therefore, what may have led professionals to administer more opioid analgesics to patients suspected of drug use than to patients not suspected, contrary to what was previously described in the literature, was patients' antisocial behavior and the recognition that, in doubt, it is better to administer analgesia. This idea is shared by some medical professionals who, in case of drug user patients, prefer to administer the analgesic than to assume the risk of not treating the legitimate pain ${ }^{(5)}$.

Another reason for increased opioid administration 'if necessary' to 'suspect' patients, as observed in the current study, could be the lower prescription of opioids at fixed times, which did not occur. When comparing the medication prescribed to patients suspected of drug use and patients not suspected (Table 3), the percentage of patients suspected with opioids prescribed at fixed times $(66.31 \%)$ was higher than that of patients not suspected (54.2\%). However, in spite of that, professionals administered the opioid 'if necessary' more 
often to patients suspected of drug use. Moreover, the majority of patients (suspected of drug use and not suspected of drug use) had non-opioid analgesics prescribed at fixed times in the same proportion $(64.7 \%$ and $67.6 \%$, respectively).

Regarding the percentage of analgesic administration 'if necessary', patients suspected of drug use received up to $30 \%$ of the maximum possible dose, while patients not suspected of drug use received up to $20 \%$ (Figure 1). The 'if necessary' doses administered were low for both groups of patients, suspected of drug use and not suspected of drug use.

The low administration of opioid analgesics in a 'if necessary' regime may be due to fear of undesirable effects of opioids (drowsiness, decreased respiratory rate, hypotension, nausea/vomiting, intestinal constipation and hallucinations, among others), fear of addiction (patient becoming addicted) or fear to 'potentiate' the existing dependency.

Studies with the nursing team observed the resistance of professionals in administering opioids for fear of iatrogenesis as side effects and development of addiction ${ }^{(23-24)}$. They administered the opioid 'if necessary' at a much lower dose than the maximum possible dose $\mathrm{e}^{(25-26)}$.

A study conducted with patients who were burned and given opioid analgesics described the abrupt discontinuation of the medication as a risk factor for respiratory depression ${ }^{(27)}$. Using opioids in treatment of acute pain in drug user patients is considered safe and should preferably be done at fixed times or through analgesia controlled by the patient. After pain relief, opioids should be withdrawn gradually and replaced by less potent ones ${ }^{(17)}$.

The fact that patients in the study are receiving adequate analgesia for acute pain situations can also be considered a justification for the low percentage of administration of opioids and non-opioids 'if necessary'. The management of acute postoperative pain requires concomitant administration of two or more analgesics with different mechanisms of action (multimodal analgesia), aiming at more effective analgesia and fewer adverse effects than monotherapy ${ }^{(28)}$. This was observed in the present study, since most prescriptions were multimodal $(89.7 \%)$.

Nursing assistants and technicians administered a similar dose of non-opioid analgesics prescribed 'if necessary' for patients suspected of drug use (33.3\%) and for those not suspected of drug use (35.7\%), as shown in table 1 . In table 4 , is observed the same similarity regarding non-opioids prescribed at 'fixed times', which were administered to $91.3 \%$ of patients suspected of drug use and to $92.6 \%$ of patients not suspected of drug use. The administration of opioids at fixed times was also very similar between patients suspected of drug use $(90.9 \%)$ and those not suspected of drug use $(89.8 \%)$, as observed in table 3 .

A noteworthy fact is that for both patients suspected of drug use and not suspected of drug use, professionals did not administer $10 \%$ of opioid analgesics and $10 \%$ of non-opioids prescribed at fixed times, totaling $20 \%$ less of prescribed analgesics (Tables 3 and 4 ). This may have happened due to the dynamics and routines of units, such as medical prescription times and medication administration schedules, discharge and return from surgical center to the unit, among others, since it is not the nursing's responsibility the decision of not administering medication prescribed at fixed times.

Data of the present study deny the hypothesis that patients suspected of drug use receive less opioid analgesics than those not suspected of drug use, but it is not possible to affirm these patients have their pain under control. Some aspects of this theme were understood and others need to be addressed. There is need for studies exploring this issue qualitatively and quantitatively.

\section{Limitations of the study}

The main objective of this study was to verify if patients suspected of drug use received more opioid analgesics than patients not suspected of drug use thus, the assessment of pain intensity was not considered relevant for the present study nor included in data collection. However, this information could be complementary data to the analysis of results.

\section{Contributions to the area of nursing, health or public policy}

This study analyzed a challenging and shortly explored situation of nursing care, which is the analgesia of patients suspected of drug use. The administration of analgesics, especially in a 'if necessary' regime, is an important nursing decision that can contribute to adequate relief of pain. Hence the importance of understanding the motivations influencing professionals in this decision.

\section{CONCLUSION}

In the opinion of nursing assistants and technicians, the prevalence of patients suspected of drug use was $6.7 \%$, and the frequency of suspicion was higher among men and young people. Professionals administered more opioids in the 'if necessary' regime for patients considered suspected of drug use than for patients not suspected of drug use ( $p=0.037)$, and the percentage of opioids prescribed in the 'if necessary' regime administered to patients suspected of drug use was up to $30 \%$ of the maximum possible dose and for patients not suspected of drug use it was up to $20 \%$ of maximum possible dose.

Professionals have administered similar doses of opioid and non-opioid analgesics prescribed at 'fixed times' for patients suspected of drug use and not suspected of drug use, and did not administer about $20 \%$ of the dose between opioids and non-opioids.

Assuming the premise that nursing professionals have correctly identified drug users, it is possible to explain that patients suspected of drug use have received more opioids because of their behavioral and emotional characteristics, i.e., greater restlessness and verbal insistence.

\section{FUNDING}

This research received financial support from the National Council for Scientific and Technological Development. 


\section{REFERENCES}

1. Guimarães CF, Santos DVV, Freitas RC, Araújo RB. Perfil do usuário de crack e fatores relacionados à criminalidade em unidade de internação para desintoxicação no hospital psiquiátrico São Pedro de Porto Alegre (RS). Rev Psiquiatr RS [Internet]. 2008 [cited 2016 Oct 10];30(2):101-8. Available from: http://www.scielo.br/pdf/rprs/v30n2/v30n2a05.pdf

2. Ponce JC, Leyton V. Drogas ilícitas e trânsito: problema pouco discutido no Brasil. Rev Psiquiatr Clin [Internet]. 2008 [cited 2016 Oct 10];35(Suppl1):65-9. Available from: http://www.scielo.br/pdf/rpc/v35s1/a14v35s1.pdf

3. Pauly BB, McCall J, Browne AJ, Parker J, Mollison AANS. Toward cultural safety: nurse and patient perceptions of illicit substance use in a hospitalized setting. Adv Nurs Sci [Internet]. 2015 [cited 2016 Oct 12];38(2):121-35.Available from: https://www.ncbi. nlm.nih.gov/pubmed/25932819

4. Tretter F. Pain and opioid dependency as multilevel network phenomenon: theoretical and metatheoretical aspects. Schmerz [Internet]. 2016 [cited 2016 Oct 20];30(4):339-49. Available from: http://download.springer.com/static/pdf/638/art \% 253A10.100 7\%252Fs00482-016-0146-1.pdf?originUrl =http\%3A\%

5. Hansem GR. The drug-seeking patient in the emergency room. Emerg Med Clin North Am [Internet]. 2005 [cited 2016 Oct 12];23(2):349-65. Available from: https://www.ncbi.nlm.nih.gov/pubmed/15829387

6. Burgess DJ, Van Ryn M, Crowley-Matoka M, Malat J. Understanding the provider contribuition to race/ethnicity disparities in pain treatment: insights from dual process models of stereotyping. Pain Med [Internet]. 2006 [cited 2016 Oct 20];7(2):119-34. Available from: https://www.ncbi.nlm.nih.gov/pubmed/16634725

7. Passik SD, Kirsh KL. Addictions in pain clinics and pain treatment. Ann N Y Acad Sci [Internet]. 2011 [cited 2016 Oct 10];1216(1):138-43. Available from: http://onlinelibrary.wiley.com/doi/10.1111/j.1749-6632.2010.05897.x/epdf

8. Manchikanti L, Giordano J, Boswell MV, Fellows B, Manchukonda R, Pampati V. Psychological factors as predictors of opióide abuse and illicit drug use in chronic pain patients. J Opioid Manag [Internet]. 2007 [cited 20146 Oct 5];3(2):89-100. Available from: https://www.ncbi.nlm.nih.gov/pubmed/17520988

9. Olsen Y, Daumit, GL, Ford DE. Opioids prescriptions by U.S. Primary care physicians from 1992 to 2001. J Pain [Internet]. 2006 [cited 2016 Oct 10];7(4):225-35. Available from: http://www.sciencedirect.com/science/article/pii/S1526590005009612

10. Huxtable CA, Roberts LJ, Somogyi AA, Macintyre PE. Acute pain management in opioi-tolerant patients: a growing challenge. Anaesth Intensive Care[Internet]. 2011 [cited 2016 Oct 5]; 39(5):804-23. Available from: https://www.ncbi.nlm.nih.gov/pubmed/21970125

11. Reis AD, Figlie NB, Laranjeira R. Prevalência do uso de substâncias em pacientes com traumas em um pronto socorro brasileiro. Rev Bras Psiquiatr [Internet]. 2006 [cited 2016 Oct 5]; 28(3):191-5. Available from: http://www.scielo.br/pdf/rbp/v28n3/09.pdf

12. Galicia M, Nogué S, Casañas X, Iglesias ML, Puiguriguer J, Supervía A, et al. Multicenter assessment of the revisit risk for a further drug-related problem in the emergency department in cocaine users (MARRIED-cocaine study). Clin Toxicol [Internet]. 2012 [cited 2016 Oct 10];50(3):176-82. Available from: https://www.ncbi.nlm.nih.gov/pubmed/22372784

13. Ferreira Filho FO, Turchi MD, Laranjeira R, Castelo A. Perfil sociodemográfico e de padrões de uso entre dependentes de cocaína hospitalizados. Rev Saúde Pública [Internet]. 2003 [cited 2016 Oct 20];37(6):751-9. Available from: http://www.scielo.br/pdf/rsp/ v37n6/18018.pdf

14. Guimarães CF, Santos DVV, Freitas RC, Araújo RB. Perfil do usuário de crack e fatores relacionados à criminalidade em unidade de internação para desintoxicação no hospital psiquiátrico São Pedro de Porto Alegre (RS). Rev Psiquiatr RS [Internet]. 2008 [cited 2016 Oct 10];30(2):101-8. Available from: http://www.scielo.br/pdf/rprs/v30n2/v30n2a05.pdf

15. Vargens RW, Cruz MS, Santos MA. Comparação entre usuários de crack e de outras drogas em serviço ambulatorial especializado de hospital universitário. Rev Latino-Am Enferm [Internet]. 2011 [cited 2016 Oct 10];19(Spe):804-12. Available from: http://www. scielo.br/pdf/rlae/v19nspe/19.pdf

16. Carlini EA, Galduróz JCF, Noto AR, Nappo SA. Il levantamento domiciliar sobre o uso de drogas psicotrópicas no Brasil: estudo envolvendo as 108 maiores cidades do país: 2005. São Paulo: CEBRID/ UNIFESP; 2006.

17. Haber PS, Demirkol A, Lange K, rnion B. Management of injecting drug users Mu admitted to hospital. Lancet [Internet]. 2009 [cited 2016 Oct 10];374(9697):1284-93. Available from: http://www.thelancet.com/pdfs/journals/lancet/PIIS0140-6736(09)61036-9.pdf

18. Morgan BD. Knowing how to play the game: hospitalized substance abusers' strategies for obtaining pain relief. Pain Manag Nurs [Internet]. 2006 [cited 2016 Oct 5];7(1):31-41. Available from: http://www.sciencedirect.com/science/article/pii/S1524904205001955

19. Finney L. Nursing care for the patient with co-existing pain and substance misuse: meeting the patient's needs. Med Surg Nurs[Internet]. 2010 [cited 2016 Oct 10];19(1):25-8. Available from: https://www.ncbi.nlm.nih.gov/pubmed/20336981

20. Millard WB. Grounding frequent flyers, not abandoning them: drug seekers in the ED. Ann Emerg Med [Internet]. 2007 [cited 2016 Oct 12];49(4):481-6. Available from: https://www.ncbi.nlm.nih.gov/pubmed/17375385

21. Jefferson DA, Harding HE, Cawich SO, Jackson-Gibson A. Postoperative analgesia in the Jamaican cannabis user. J Psychoactive Drugs [Internet]. 2013 [cited 2016 Oct 5];45(3):227-32. Available from:http://www.tandfonline.com/doi/abs/10.1080/02791072.2013.803644 
22. Grover CA, Close RJH, Wiele ED, Villarreal K, Goodman LM. Quantifying drug-seeking behavior: a case control study. J Emerg Med [Internet]. 2012 [cited 2016 Oct 10];42(1):15-21. Available from:http://www.sciencedirect.com/science/article/pii/S0736467911006329

23. Murnion BP, Gnjidic D, Hilmer SN. Prescription and administration of opioids to hospital in-patients, and barriers to effective use. Pain Med [Internet]. 2010 [cited 2016 Oct 12];11(1):58-66. Available from:http://painmedicine.oxfordjournals.org/content/ painmedicine/11/1/58.full.pdf

24. Nascimento LA, Santos MR, Aroni P, Martins MB, Kreling MCGd. Manejo da dor e dificuldades relatadas pela equipe de enfermagem na administração de opioides. Rev Eletrônica Enferm [Internet]. 2011 [cited 2016 Oct 10];13(4):714-20. Available from: https://www.fen.ufg.br/fen_revista/v13/n4/pdf/v13n4a16.pdf

25. McCaffery M, Ferrell BR. Nurses' knowledge of pain assessement and management: how much progress have we made? J Pain Symptom Manage [Internet].1997 [cited 2016 Oct 20];14(3):175-88. Available from: http://www.sciencedirect.com/science/ article/pii/S088539249700170X

26. Henrique DM, Silva LD, Pareira SRM. Características del paciente quemado usuario de opioide y factores que contribuyen a depresión respiratória. Enferm Glob [Internet]. 2016 [cited 2016 Oct 10];15(3):125-37. Available from: http://revistas.um.es/ eglobal/article/view/216931/194641

27. Estrela KSR, Loyola CMD. Administração de medicação de uso quando necessário e o cuidado de enfermagem psiquiátrica. Rev Bras Enferm [Internet]. 2014 [cited 2016 Oct 10];67(4):563-7. Available from: http://www.scielo.br/pdf/reben/v67n4/0034-7167-reben-67-04-0563.pdf

28. American Society of Anestesiologists. Practice guidelines for acute pain management in the perioperative setting. Anesthesiol [Internet]. 2012 [cited 2016 Oct 10];100(6):248-73. Available from: http://anesthesiology.pubs.asahq.org/article.aspx?articleid = 1933589 